\title{
CHEMICAL COMPOSITIONS AND ANTIMICROBIAL ACTIVITY OF THE LEAF ESSENTIAL OIL OF GOSSYPIUM HIRSUTUM
}

\section{Ogunmola Oluranti O. ${ }^{1}$}

${ }^{1}$ Department of Chemistry, Emmanuel Alayande College of Education, Oyo. Oyo State, Nigeria.

\begin{abstract}
The study was conducted to analyze the chemical constituent and to evaluate the antimicrobial properties of the leaf essential oil of Gossypium hirsutum. The oil was obtained by hydrodistillation and was analyzed by gas chromatography and gas chromatography -mass spectrometry $(G C / G C-M S)$. This revealed the presence of fifty components accounting for - \% of the total oil fraction. The leaf oil was dominated by patchoulane (14.70\%), Ally 1-2, 6,6 trimethyl bicyclo (3.1.1) heptane (5.95\%). 1,7, 7 - trimethyl bicyclo (2.2.1) heptanes (5.95\%) and 9- (1 - methylethylidene) bicyclo (6.1.0) nonane (5.95\%). The oil displayed high antimicrobial potentials to some tested micro organisms.
\end{abstract}

KEYWORDS: Gossypium hirsutum, patchoulane, aliphatic alcohol, antimicrobial potential.

\section{RESUMO}

O estudo foi conduzido para analisar o constituinte químico e avaliar as propriedades antimicrobianas do óleo essencial de folha de Gossypium hirsutum. O óleo foi obtido por hidrodestilação e analisado por cromatografia gasosa e cromatografia gasosa-espectrometria de massa (GC / GC-MS). Isso revelou a presença de cinqüenta componentes representando -\% da fração de óleo total. O óleo de folha foi dominado por patchoulane (14,70\%), Ally 1-2, 6,6 trimetilbiciclo (3.1.1) heptano (5,95\%). 1,7, 7-trimetilbiciclo (2.2.1) heptanos (5,95\%) e 9- (1metiletilideno) biciclo (6.1.0) nonano (5,95\%). O óleo apresentou potenciais antimicrobianos elevados para alguns microrganismos testados.

PALAVRAS CHAVE: Gossypium hirsutum, patchoulene, álcool alifático, potencial antimicrobiano

\section{Introduction}




\section{SOUTHERN BRAZILIAN JOURNAL OF CHEMISTRY \\ SOUTH. BRAZ. J. CHEM., Vol. 23, No. 23, 2015 \\ 92 \\ Ogunmola Oluranti $\mathbf{O}$.}

Plants are one of the five main groups of living things, these groups are called kingdoms. The plant kingdom includes such living things as grasses, trees, ferns, bushes and flowers. About 260,000 species of plant exist on the earth (14) plant contains complex and powerful substances known as essential oils. These are aromatic liquid derived from shrubs, flowers, trees, roots, bushes, herbs and seeds (15). Medicinal plants form an aspect of cultural heritage of the human race and their use is still expanding. Plants with useful medicinal properties have been obtained from folklore records of many indigenous communities. Egyptian and Chinese priests and physicians since time immemorial had been using extracted oils from plant for healing and this makes essential oil the earliest known medicine (15). An essential oil is a concentrated hydrophobic liquid containing volatile aroma compounds from plants. It is also known as volatile oils, ethereal oils or aethrolea or simply as the "oil of' the plant from which they were extracted. An oil is "essential" in the sense that it carries a distinctive scent or essence of the plant (16).

Gossypium hirsutum L. (family malvaceae) is a cotton specie native to Central America and the Caribbean. After being domesticated in the United States, this cotton species now provides over $90 \%$ of commercial cotton worldwide (13). In Nigeria, cotton seed provides raw materials for local spinning and weaving industry (4). It is believed to be an indigenous effective medicinal plant. The dried root bark of cotton contains gossypol, this compound may cause abortion - inducing effect (3). Gossypol is a polyphenol that may be isolated more easily from the bark (5). There is on going research to use gossypol as an alternative to vasectomy (7), the plant is known to 
SOUTH. BRAZ. J. CHEM., Vol. 23, No. 23, 2015

CHEM. COMP. AND ANTIMI. AC. OF ESSENTIAL OIL OF GOSS. HIR.

posses anti-malaria properties and it has demonstrated in vitro effects on cell regulation and antitumor activity against mammary carcinoma a cell lines $(9,18,6)$.

When the chemical constitution of the essential oil of six species within three genera of the family malvaceae were investigated, the essential oil of Gossypium tursutum L. was found to contain $67.0 \%$ hydrocarbon and beta-bisabolol was the major oxygenated component $13.7 \%$ (1),also (12) reported the presence of fifty nine constituents in the oil aroma of Gossypium barbadense in which patchoulane (7.94\%), Bicyclo (4.1.0) heptanes -3-cylopropy 1-7-hydroxymethyl (trans) (7.86\%), ZNonadecatetraene $(6.19 \%)$, alpha-patchoulane $(6.19 \%)$, caryophyllene oxide $(5.75 \%)$ and Bicyclo (7.2.0) undec-4-ene, 11, 11-trimethy 1-8-methylene $\left(\mathrm{IR}^{*}, 4 \mathrm{z}, 95^{*}\right)(3.50 \%)$ as the major constituents. The oil also has antibiotic potential $(12,13)$.

\section{Materials and Methods}

\section{Plant Material}

Leaves of Gossypium hursutum were collected from Oyo, south West, Nigeria. The plant was authenticated at the Forest Research Institute of Nigeria (FRIN) Ibadan, Nigeria. Extraction of the hursutum was air dried in a well ventilated place till when the moisture content reduced to a minimum suitable for grinding. The plant material was pulverized and used immediately. The crushed plant material $(400 \mathrm{~g})$ was subjected to hydrodistillation for 3 hours using a Clevenger - type apparatus (11). The oil collected was stored in a vial at low temperature until the time of the analysis. 


\section{SOUTHERN BRAZILIAN JOURNAL OF CHEMISTRY}

SOUTH. BRAZ. J. CHEM., Vol. 23, No. 23, 2015

Ogunmola Oluranti $\mathbf{O}$.

\section{Multidimensional GC X GC-MS Analysis}

Analysis of leaf essential oil of Gossypium barbadense was performed using multidimensional chromatogram coupled with gas chromatography, mass spectrometer (Shimadzu, Japan,) equipped with double capillary columns $\left(2.50 \mathrm{~m} \times 0.25^{\mathrm{N}} \mathrm{m}\right.$ I.d, $0.25^{\mathrm{N}} \mathrm{mdf}$ ) that have different characteristics (non polar and polar) High purity helium was used as the carrier gas at a constant flow rate of $0.99 \mathrm{ml} / \mathrm{min}$. A total of $1 \mathrm{Nl}$ sample was injected (Split ratio 100:1) into GC X GC MS using AOC 20i auton injector for analysis. The initial temperature was set at $60^{\circ} \mathrm{C}$ treated at a rate of $30^{\circ} \mathrm{C}$ minute to $28^{\circ} \mathrm{C}$ and held isothermally for 6 minutes. Ion source temperature for this analysis was set at $200^{\circ} \mathrm{C}$ while the interface temperature was set at $250^{\circ} \mathrm{C}$ solvent cut time was 3.0 minutes and the mass spectrometer was set to operate in electron ionization mode with an ionizing energy of $70 \mathrm{eV}$ as acquisition mass range from $40-700$ a.m.N at $0.50 \mathrm{cscan} / \mathrm{S}$.

\section{Antimicrobial Activities}

The antibacterial activity of the leaf essential oil of Gossypium barbadense was measured against Grain-negative (Esherichia coli, klebsiella pneumonae, salmonella typhimourion and proteins mirabilis) and Grain - positive (staphytlococcus aureus and streptococcus agalactiae) using a well diffusion method according to the National Committee for Clinical Laboratory Standard (13). Petri plates containing approximately $25-30 \mathrm{ml}$ of nutrient agar medium were swabbed using cotton applicator with 24 hours sub-cultured bacteria strains which were prepared in dilution to match the turbidity intensity of the MacFarland standard. Wells (6mm diameter) were punched in the agar 
CHEM. COMP. AND ANTIMI. AC. OF ESSENTIAL OIL OF GOSS. HIR.

and filled $10^{\mathrm{N}} \mathrm{L}$ of the extract of different concentration $\left(1000,100\right.$ and $\left.10 \mathrm{Ngml}^{-1}\right)$. The plates were incubated at $37^{\circ} \mathrm{C}$ for 24 hours. The antibacterial activities were assessed by measuring the inhibition zone diameter $(\mathrm{mm})$ around the well.

\section{Results and Discussion}

Exhaustive hydro distillation of the leaf of Gossypium hursutum gave a light yellow coloured oil with $0.4 \% \mathrm{~V} / \mathrm{W}$ yield per $400 \mathrm{~g}$ of dried leaf sample. The analysis of the leaf essential oil was carried out using GC X GC - MS and the percentage compositions are given in table 1. Fifty compounds were identified from the leaf essential oil amounting to $-\%$ of the oil. The leaf essential oil was dominated by patchoulane (14.70\%) Allyl -2 , 6, 6 - trimethyl bicyclo (3.1.1) heptanes (5.95\%), 1, 7, 7- Trimethyl bicyclo (2.2.1) heptanes (5.95\%) and 9-(1-methyl-ethylidene) bicyclo (6.1.0) nonane (5.95\%). The composition of the essential oil has similarity with the constituent of Gossypium barbadense reported by (12), patchovlane, been the compound with the highest percentage in Gossypium barbadense has the highest percentage in Gossypium hirsutum(14.70\%). The aliphatic reported by (12) as part of the constituents of Gossypium barbadense are also in the present study even though it is quantitatively

different (6 - Mehthyl-2-Vingl-5-hepten-01 (1.30\%), 2- pentadecen-1-01 (1.30\%) and Z - 10-pentadecen-1-01.

In addition, the oil displayed high antimicrobial activities to proteus micrabelis at 1,000, 100 and $10 \mathrm{Ngml}^{-1}$, Esherichia coli at 1,000, 100 and $10 \mathrm{Ngml}^{-1}$, staphylococcus aureus at 1,000, 100 and $10 \mathrm{Ngml}^{-1}$ and klebsiell pneumonia at 1,000, 100 and $10 \mathrm{Ngml}^{-1}$ as shown in table 2. The oil also displayed low inhibitory activity against gram negative 


\section{SOUTHERN BRAZILIAN JOURNAL OF CHEMISTRY \\ SOUTH. BRAZ. J. CHEM., Vol. 23, No. 23, 2015 \\ Ogunmola Oluranti 0.}

96

salmonella typhimurium at all concentrations and this can antibiotics as shown in table

3.

\section{Conclusion}

The result obtained in this study showed that Gossypium hirustum possess essential oil and it has a great antibiotics potential and this confirm its use in traditional medicine as an antibiotics and anti-malaria.

\section{Table I}

Chemical Constituents of the essential oil of Gosspium Hirustum.

\begin{tabular}{|l|l|l|l|}
\hline S/N & R.I & Compound & \% Comp \\
\hline 1. & 1061 & 2 (3H) - Furanone & 2.00 \\
\hline 2. & 837 & 2 - Pentanethol & 4.00 \\
\hline 3. & 935 & Nitrohexane & 2.00 \\
\hline 4. & 919 & Pyruvic acid, Methylester oxime & 2.00 \\
\hline 5. & 620 & 3 - Ethoxy-1-butene & 0.58 \\
\hline 6. & 1273 & $3,5-$ Octanedione, 2, 2, 4, 7- tetramethyl & 0.58 \\
\hline 7. & 821 & Pentanal, 2, 2- dimethyl & 0.58 \\
\hline 8. & 676 & Tert - butylcarbinol & 0.58 \\
\hline 9. & 729 & Methyl -2-2methyoxyacrylate & 0.58 \\
\hline 10. & 1515 & Germacrene & 0.2 \\
\hline 11. & 1221 & Copane & 0.4 \\
\hline 12. & 1440 & Alpha - Amorphene & 0.2 \\
\hline
\end{tabular}


SOUTHERN BRAZILIAN JOURNAL OF CHEMISTRY

SOUTH. BRAZ. J. CHEM., Vol. 23, No. 23, 2015

CHEM. COMP. AND ANTIMI. AC. OF ESSENTIAL OIL OF GOSS. HIR.

\begin{tabular}{|c|c|c|c|}
\hline 13. & 1458 & $(\mathrm{Z}, \mathrm{Z})$ alpha - Farnesene & 0.2 \\
\hline 14. & & 2, 6 - Bis (diazn) adamatane & 0.32 \\
\hline 15. & 1050 & 2, 8 - Decadiyne & 0.32 \\
\hline 16. & 1229 & Ethanone-1-2-5 (methyl)-2 forylcycloprophyl & 0.32 \\
\hline 17. & 2139 & $\begin{array}{l}\text { Benzene, 2-pheyl-2-propenyl) sulfonl oxacyclo tetradeca-4, } \\
\text { 11-ddiyne }\end{array}$ & 0.32 \\
\hline 18. & 1393 & Patcheulane & 14.70 \\
\hline 19. & 1148 & 1-Methyl-2-methylene-3, 5-divinyl cyclohexane & 1.40 \\
\hline 20. & 1494 & 4,11, 11-Trimethyl-8-methylene bicyclohexane & 1.40 \\
\hline 21 & 1369 & Cyclohexene, 4-180 propenyl-1-methoxymethyl & 1.40 \\
\hline 22. & 1579 & Alpha Humulene & 0.63 \\
\hline 23. & 958 & Ocimene & 1.26 \\
\hline 24. & 976 & Beta-CIS-Ocimene & 1.26 \\
\hline 25. & & $\begin{array}{l}\text { 3-Methyl-4-(phenylthia)-2-prop-2-enyl-2, } \\
\text { phenel, 1-dioxide }\end{array}$ & 0.57 \\
\hline 26. & & Lauryl pyridinium chloride & 0.57 \\
\hline 27. & 1128 & Pentanol-5- (methylene Cyclopropyl) & 0.57 \\
\hline 28. & 1934 & Z, Z, Z-4, 6, 9- Nonadecatriene & 0.57 \\
\hline 29. & 1414 & 1, 2-Epoxy - 5, 9-Cyclododecadiene & 0.57 \\
\hline 30 & 1187 & Allyl - 2, 6, 6 - trimethyl bicoclo (3.1.1) heptanes & 5.95 \\
\hline 31. & 1326 & 1, 7, 7 - trimethyl bicyclo(2.2.1) heptanes & 5.95 \\
\hline
\end{tabular}


SOUTHERN BRAZILIAN JOURNAL OF CHEMISTRY

SOUTH. BRAZ. J. CHEM., Vol. 23, No. 23, 2015 98

Ogunmola Oluranti 0.

\begin{tabular}{|c|c|c|c|}
\hline 32. & 1242 & 9 - (1 - Methylethylidene) bicycle (6.1.0) nonane & 5.95 \\
\hline 33. & 1066 & 1-(I-Methylene-2-propenyl) cyclopentanol & 1.56 \\
\hline 34. & 1307 & $\begin{array}{l}\text { Bicyclo (4.1.0) heptanes-3-cyclopropy 1-7-hydroxymethyl } \\
\text { trans }\end{array}$ & 1.56 \\
\hline 35. & 1307 & Bicuclo (4.1.0) heptanes-3-cycloprophy1-7-hydroxymethyl cis & 1.56 \\
\hline 36. & 1078 & 1-(2-Methylene cyclopropyl) cyclopentanol & 1.56 \\
\hline 37. & 1143 & Ethyhdene cyclo octane & 1.56 \\
\hline 38. & 1196 & Dihydrocarveol & 1.30 \\
\hline 39. & 1169 & 6 - Methyl - 2-Vinyl-5-hepten-1-01 & 1.30 \\
\hline 40. & 1772 & 2 - Pentadecyn-1-01 & 1.30 \\
\hline 41. & 1292 & Myrcenylacetate & 1.30 \\
\hline 42. & 1079 & Isothujol & 1.30 \\
\hline 43. & 1968 & Palmitic acid & 3.27 \\
\hline 44. & 1272 & Pelargic acid & 1.09 \\
\hline 45. & 1769 & Myristic acid & 1.09 \\
\hline 46. & 2175 & Cis-Oleic acid & 4.00 \\
\hline 47. & 1763 & Z-10-pentadecen-1-01 & 4.00 \\
\hline 48. & 2007 & 9 - Octadecenal & 4.00 \\
\hline 49. & 1763 & E-10-Pentadecen-1-01 & 4.00 \\
\hline \multirow[t]{2}{*}{50.} & 1293 & $10-$ Undecenal & 4.00 \\
\hline & & Total & \\
\hline
\end{tabular}


SOUTHERN BRAZILIAN JOURNAL OF CHEMISTRY

SOUTH. BRAZ. J. CHEM., Vol. 23, No. 23, 2015

CHEM. COMP. AND ANTIMI. AC. OF ESSENTIAL OIL OF GOSS. HIR.

\section{Table 2}

Zones of inhibition $(\mathrm{mm})$ showing the antimicrobial activities of gram-negative and grampositive bacteria.

\begin{tabular}{|c|c|c|c|c|c|c|}
\hline Organism & $\begin{array}{l}\text { Escherichia } \\
\text { Coil }\end{array}$ & $\begin{array}{l}\text { Klebsiella } \\
\text { Pneumonia }\end{array}$ & $\begin{array}{l}\text { Salmonella } \\
\text { Typhimouriu } \\
\text { m }\end{array}$ & $\begin{array}{l}\text { Proteus } \\
\text { Mirabelis }\end{array}$ & Staphylococos & streptococcos \\
\hline $\begin{array}{l}\text { Conc. } \\
\left(\mathrm{Ngml}^{-1}\right)\end{array}$ & $\begin{array}{ll}1,000 & 100 \\
10 & \end{array}$ & 1,000 & 1,00010010 & $\begin{array}{l}1,000 \\
10010\end{array}$ & 1,00010010 & 1,00010010 \\
\hline $\begin{array}{l}\text { Zone of } \\
\text { inhibition }\end{array}$ & 201710 & 151515 & $09 \quad 08 \quad-$ & $\begin{array}{ll}32 & 30 \\
24 & \end{array}$ & $20 \quad 20 \quad 20$ & $\begin{array}{ll}11 & 11\end{array}$ \\
\hline
\end{tabular}

Keynote: - = no inhibition, 6-9mm = low inhibition, $10-15 \mathrm{~mm}=$ moderate inhibition

$$
\begin{aligned}
& \text { And } \geq 15 \mathrm{~mm}=\text { high inhibition } \\
& +- \text { = gram-negative bacteria } \\
& { }^{*}=\text { gram-positive bacteria }
\end{aligned}
$$

\section{Table 3}

Zones of inhibition $(\mathrm{mm})$ showing the antimicrobial activities of antibiotics against gram positive and gram negative bacteria.

\begin{tabular}{|l|l|l|l|l|l|l|}
\hline $\begin{array}{l}\text { Organism/ } \\
\text { antibiotics/ } \\
\text { concentration }\end{array}$ & $\begin{array}{l}\text { Escherichia } \\
\text { Coil }\end{array}$ & $\begin{array}{l}\text { Klebsiella } \\
\text { Pneumonia }\end{array}$ & $\begin{array}{l}\text { Salmonella } \\
\text { Typhimouriu } \\
\mathbf{m}\end{array}$ & $\begin{array}{l}\text { Proteus } \\
\text { Mirabelis }\end{array}$ & $\begin{array}{l}\text { Staphylococus } \\
\text { aureus }\end{array}$ & $\begin{array}{l}\text { streptococcus } \\
\text { agalactiae }\end{array}$ \\
\hline $\begin{array}{l}\text { Nitrcoforantion } \\
(2 \mathrm{Ng})\end{array}$ & 25 & 20 & 15 & 15 & 28 & 11 \\
\hline $\begin{array}{l}\text { Ofloxacin } \\
(5 \mathrm{Ng})\end{array}$ & 20 & 20 & 22 & 33 & 20 & - \\
\hline $\begin{array}{l}\text { Gentamicin } \\
(10 \mathrm{Ng})\end{array}$ & 24 & 15 & 18 & 16 & - & - \\
\hline
\end{tabular}

Keynote: - Same as in table 2. 


\section{SOUTHERN BRAZILIAN JOURNAL OF CHEMISTRY \\ SOUTH. BRAZ. J. CHEM., Vol. 23, No. 23, 2015 \\ Ogunmola Oluranti $O$.}

100

\section{References}

1. Thompson, A. C., Hanny, B. W., Hedin, P. A. and Gueldner, R. C. (1971) Phytochemical Studies in the family maluaceae 1 . Comparison of essential oils of six species by gas - liquid chromatography. American Journal of Botany 58: 9. Pp 803-907.

2. Gossypium Tincture from Amazon herbs. Retrieved from Tropilan inc., exporter \& wholesaler of medicinal plants herbs and tropical seeds on 27-05-15.

3. www. naturalstandard.com. Accessed $27^{\text {th }}$ May 2015.

4. Esssien, E. E., Aboaba, S. O. and Ogunwande, I. A. (2011) Constituents and Antimicrobial properties of the leaf essential oil of Gossypium barbadense (linn). Journal of Medicinal Plant Research 5 (5) Pp 702-705.

5. Zhou, R. H., and Lin, X. D. (1988) Isolation of (-) -gossypol from natural plant. Contraceptives, 37: Pp $239-245$.

6. Ajaiyeoba, E. O., Falade, C. O, Fawole, O. I., Akinboye, D. O., Gbotosho, G. O., Bolaji, O. M., Ashidi, J. S., Abiodun, O. O., Osowole, O. S., Itiola, O. A., Oladepo, O., Sowumi, A. and Oduola, A. M, (2004) Efficacy of herbal remedies used by herbalist in Oyo State Nigeria for treatment of Plasmoduim falciparum Infections - a survey and observation. African Journal of Medicinal Science 33 (2) Pp 115199.

7. Qian, S. Z. and Wang, Z.G. (1984) Gosspoly: a potential antifertility agent for males. Animal Review of Pharmacological Toxicology 24: $329-360$.

8. Liu, G. Z, Lyle, K. C and CaOJ. (1987) Clinical trail of gossypol as a male contraceptive drug. Part I. efficacy study. Fertile. Steril 48 93) $459-461$.

9. Shidaifat, F. (1996) Inhibition of human postrate cancer cells growth by gossypol Associated with stimulation of transforming growth factor-beta. Cancer letter 107 (1): 37-44.

10. National Committee for Clinical Laboratory standards (1993) Retrieved online from www.nchi.nlm.gov/pmc.on 17-07-14.

11. European Pharmacopoela Commission (2004). European Pharmacopoeia $5^{\text {th }}$ Ed. Council of Europe: Strasbourg Cedex, France.

12. Ogunmola, O. O. and Larayetan, R. A. (2015) Chemical and medicinal potentials of the leaf essential oil of Gossypium barbadense L. Brazilian Journal of Chemistry.

13. Chan, B. G, Waiss Jr. A. C, Lukefahr, M. J (1978) Condensed tuning an antibiotic Chemical from Gossypium hirsutum. Journal of insect physiology 24: $113-118$.

14. Microsoft Encarta, (2009)

15. Smyrna (2006)

16. Schnaublet (1999)

17. www.naturalstandard.com

18. Salako, O. A. and Awodele, O. (2012) Evaluation of the antimalaria activity of the aqueous leaf extract of Gossypium barbadense (Malvaeceae) in mice. Drugs and Therapy studies 2 (2) Pp 1-7. 